\title{
THE GRAIN YIELD AND WEED INFESTATION RATE OF WINTER WHEAT BY THE DIFFERENT SHARE OF CEREALS IN CROP ROTATIONS
}

\author{
MÁRIA BABULICOVÁ, L'UBOMÍR MENDEL
}

Plant Production Research Center Piešt’any

BABULICOVÁ, M. - MENDEL, L'.: The grain yield and weed infestation of winter wheat by the different share of cereals in crop rotations. Agriculture (Pol’nohospodárstvo), vol. 57, 2011, no. 1, pp. 31-40.

The aim of the study was to compare the grain yield and weed infestation rate of winter wheat in crop rotations with 40, 60 and $80 \%$ share of cereals and in continuous cropping. The trial was situated in the area of continental climate. The trial had two parts. In the first part, there were crop rotations with 40, 60 and $80 \%$ share of the cereals. Two levels of fertilization were used: H1 mineral fertilization + organic manure Veget; H2 mineral fertilization only. In the second part, winter wheat and spring barley were grown in monoculture. Three variants of fertilization were used: 1 - mineral fertilization; 2 - mineral fertilization + straw of cereals were ploughed; 3 - mineral fertilization + straw of cereals + organic manure
Veget were ploughed in the soil. In the years 2006-2009 the grain yield, thousand kernel weight and weed infestation rate of winter wheat in different crop rotations and by the continuous cropping were investigated. The statistically higher winter wheat grain yield $\left(6.50 \mathrm{tha}^{-1}\right)$ was recorded by $40 \%$ share of cereals in crop rotation than by $60 \%$ and $80 \%$ share of cereals $\left(6.23 \mathrm{tha}^{-1}\right)$. The grain yield of winter wheat by continuous cropping was lower by $2.24 \mathrm{t} \mathrm{ha}^{-1}(34.46 \%)$ than in crop rotation with $40 \%$ share of cereals. The weed infestation rate by $80 \%$ share of cereals in crop rotation was determined 2.4 times higher than by $40 \%$ share of cereals.

Key words: crop rotation, continuous cropping, winter wheat, grain yield, weed infestation rate

\section{INTRODUCTION}

The systems of crop rotations in agricultural production are always one of the main agrotechnical measures, which contribute to the increasing of plant production. By rotating the crops we utilize the abilities of some agricultural crops to affect favourably the physical, chemical and biological soil properties. In terms of economic management and the conservation of soil fertility, the crop rotation is irreplaceable. The disrupted balance of agricultural production can be compensated by the well-considered crop rotation with different requirements, for example of a certain nutrient taking. The sequence of crops with a relative share of fertilizing crops improves soil structure, affects soil biodiversity and the content of organic matter with its harvested residua; it also influences the nutrients drawing from soil and affects the environment favourably. The foreign and national experiences prove that the enterprises specialize on the high share of cereals and the measurement of root-crops decreases. In crop rotations the share of cereals integrated after cereals or after oil plants increased markedly. By increasing the share of cereals in crop rotation we expect the decreasing of the grain yield. The decreasing of grain yield is brought about by the damage caused by fungal diseases, the increasing weed infestation rate, as well as the degradation of soil structure and by its negative impact on water and air soil regime. Ellmer and Baumecker (2005) investigated how crop rotations with 50\%, 75\% and $100 \%$ cereal concentration influence the soil status and yield development. With the results of these

Ing. Mgr. Mária Babulicová, PhD., Ing. Lubomír Mendel, PhD., Plant Production Research Center Pieštany - Research Institute of Plant Production Pieštany, 92168 Pieštany, Bratislavská 122, Slovak Republic. E-mail: babulicova@vurv.sk; mendel@vurv.sk 
long-term experiments it was possible to deduce a ranking of agronomic factors influencing the soil organic matter content at sandy soil: organic fertilization $(+37 \%)>$ crop rotation $(+30 \%)>$ mineral $\mathrm{N}$ fertilization $(+20 \ldots 26 \%)>$ irrigation $(+2 \ldots 7 \%)$. Jamriška et al. (2006) researched the influence of a cultivar and the agrotechnical measures on the grain yield and the quality of winter wheat. The fertilization of winter wheat by nitrogen did not affect the grain yield, but decreased the thousand kernel weight.

In economic and biological terms the continuous cropping has the most expressive negative effects. Rychlik et al. (2005) observed the regime of soil organic matter in two crop rotations: A) potato - oats - flax - winter rye - faba bean - winter triticale; B) sugar beet - maize - spring barley - pea - winter rape - winter wheat. In addition, each crop was grown in continuous cropping as well. Under the conditions of the crop rotation, a slight increase occurred in the content of organic matter; similar tendencies appeared in most monoculture fields. The increasing of humus in crop rotation A was $0.19 \%$, in crop rotation B $0.37 \%$. The increasing of humus $0.4 \%$ was found under the conditions of continuous cultivation of spring barley, oats, flax, winter rye and oats. Humic acids prevailed over fulvic acids in the crop rotation cultivations and in most monocultural fields. However, prevalence of fulvic acids was found under the conditions of continuous cultivation of sugar beet, potato and winter rye.

Hoffman et al. (2005) observed the effect of straw fertilization on the dynamics soil organic matter and soil fertility. They found out that an accurate observation of the impact of straw incorporation on the soil fertility is difficult because the change of organic matter is very slow. The evaluation of these changes is demanding because in the top soil layer there are respectable supplies of organic matter. Remešová et al. (2002) investigated the influence of different soil tillage and straw management on the weed spectrum. The number of individual weed species was determined in the area

$\mathrm{T}$ a

Weather conditions in the experimental years on the stand Borovce

\begin{tabular}{|c|c|c|c|c|c|c|c|c|c|c|}
\hline \multirow{3}{*}{ Month } & \multicolumn{2}{|c|}{ n (1951-1980) } & \multicolumn{2}{|c|}{2006} & \multicolumn{2}{|c|}{2007} & \multicolumn{2}{|c|}{2008} & \multicolumn{2}{|c|}{2009} \\
\hline & $\bar{x}_{t d}$ & $\sum$ & $\overline{\mathrm{x}}_{\mathrm{td}}$ & $\sum$ & $\overline{\mathrm{x}}_{\mathrm{td}}$ & $\sum$ & $\overline{\mathrm{x}}_{\mathrm{td}}$ & $\sum$ & $\overline{\mathrm{x}}_{\mathrm{td}}$ & $\sum$ \\
\hline & {$\left[{ }^{\circ} \mathrm{C}\right]$} & {$[\mathrm{mm}]$} & {$\left[{ }^{\circ} \mathrm{C}\right]$} & {$[\mathrm{mm}]$} & {$\left[{ }^{\circ} \mathrm{C}\right]$} & {$[\mathrm{mm}]$} & {$\left[{ }^{\circ} \mathrm{C}\right]$} & {$[\mathrm{mm}]$} & {$\left[{ }^{\circ} \mathrm{C}\right]$} & {$[\mathrm{mm}]$} \\
\hline January & -1.8 & 32.0 & -4.82 & 47.1 & 3.47 & 53.1 & 1.48 & 25.5 & -2.03 & 29.9 \\
\hline February & 0.2 & 33.0 & -2.24 & 30.1 & 4.32 & 36.2 & 2.46 & 15.1 & 1.05 & 64.8 \\
\hline March & 4.2 & 32.0 & 2.10 & 25.3 & 7.65 & 56.0 & 4.73 & 47.8 & 5.27 & 58.5 \\
\hline April & 9.4 & 43.0 & 11.53 & 52.7 & 11.32 & 0.0 & 11.07 & 31.2 & 14.45 & 6.0 \\
\hline May & 14.1 & 54.0 & 14.75 & 66.5 & 16.50 & 58.9 & 16.84 & 36.4 & 16.02 & 47.0 \\
\hline June & 17.7 & 80.0 & 18.99 & 136.2 & 20.36 & 55.7 & 21.16 & 65.9 & 18.40 & 58.5 \\
\hline July & 18.9 & 76.0 & 22.96 & 0.5 & 21.28 & 33.8 & 21.35 & 89.6 & 22.44 & 81.0 \\
\hline August & 18.4 & 68.0 & 17.31 & 83.7 & 20.70 & 93.6 & 20.72 & 71.0 & 22.48 & 52.0 \\
\hline September & 14.5 & 38.0 & 17.21 & 0.0 & 12.78 & 109.6 & 15.27 & 50.5 & 18.40 & 9.7 \\
\hline October & 9.6 & 42.0 & 12.38 & 30.0 & 8.64 & 34.0 & 10.65 & 33.1 & 9.48 & 55.5 \\
\hline November & 4.6 & 51.0 & 7.43 & 49.4 & 2.76 & 36.2 & 6.55 & 37.0 & 5.84 & 51.0 \\
\hline December & 0.3 & 46.0 & 2.93 & 13.3 & -1.00 & 32.0 & 2.27 & 29.0 & 0.74 & 70.0 \\
\hline$\overline{\mathrm{x}}_{\mathrm{td}}\left[{ }^{\circ} \mathrm{C}\right]$ & 9.2 & - & 10.04 & - & 10.73 & - & 11.21 & - & 11.02 & - \\
\hline$\sum[\mathrm{mm}]$ & - & 595 & - & 534.8 & - & 599.1 & - & 532.1 & - & 584.0 \\
\hline
\end{tabular}

$\mathrm{n}$ - long-term (30-year) normal

$\overline{\mathrm{x}}_{\mathrm{td}}-$ average air temperature

$\Sigma-$ sum of precipitation 
$0.25 \mathrm{~m}^{2}$ of the winter wheat stand by the method of weed counting. Winter wheat was grown in crop rotation (peas, winter wheat, spring barley, oil plant, winter wheat, winter wheat). The highest weed infestation rate was ascertained when winter wheat followed after winter wheat. The highest number of weeds was found in the variant with stubble ploughed under in the depth $0.12-0.15 \mathrm{~m}$, by sowing with exact drill and by burning the straw.

The main objective of our study was to evaluate the impact of different share of cereals in crop rotations and fertilization on the grain yield, thousand kernel weight and weed infestation rate of winter wheat in 2006 and 2009. By continuous cropping of winter wheat the impact of fertilization and cultivar on the grain yield and thousand kernel weight and was evaluated.

\section{MATERIAL AND METHODS}

The present results are the component of findings from long-term field experiment which was established in 1974 in the maize producing area in experimental station Borovce -West Slovakia - belonging to the Plant Production Research Center. The field experiment was located on Luvi-Haplic Chernozem on loess. The depth of plow-layer was $0.24-0.28 \mathrm{~m}$. The depth of molic horizon was $0.40-0.55 \mathrm{~m}$; it was differentiated in the upper (eluvial) and under (illuvial) layer. In the depth of $0.50-0.85 \mathrm{~m}$ the molic horizon proceeded into calciferous loess. The content of humus was medium (1.8-2.0\%), in the plowpan it was low. The soil was characterized by mean to good content of phosphorus, good to high content of potassium, high content of magnesium (the analysis according to Meh-

$\mathrm{T}$ a b 1 e 2

The crop rotations with 40,60 , and $80 \%$ share of the cereals

\begin{tabular}{|l|l|l|}
\hline \multicolumn{2}{|c|}{ Crop rotation } \\
\hline $40 \%$ cereal portion & $60 \%$ cereal portion & $80 \%$ cereal portion \\
\hline 1. pea & 1. pea & 1. winter wheat \\
2. winter wheat & 2. winter wheat & 2. spring barley \\
3. silage maize & 3. winter barley & 3. pea \\
4. spring barley & 4. silage maize & 4. winter wheat \\
5. grain maize & 5. spring barley & 5. winter barley \\
\hline
\end{tabular}

$\mathrm{T}$ a b 1 e 3

The fertilization in crop rotations with $40 \%, 60 \%$ and $80 \%$ cereals

\begin{tabular}{|c|c|}
\hline $\mathrm{H}_{1}$ & $\mathrm{H}_{2}$ \\
\hline $\mathrm{N} 90 \mathrm{~kg} \mathrm{ha}^{-1}$ & $\mathrm{~N} 120 \mathrm{~kg} \mathrm{ha}^{-1}$ \\
$\mathrm{P} 10 \mathrm{~kg} \mathrm{ha}^{-1}$ & $\mathrm{P} 15 \mathrm{~kg} \mathrm{ha}^{-1}$ \\
$\mathrm{~K} 25 \mathrm{~kg} \mathrm{ha}^{-1}$ & $\mathrm{~K} \mathrm{25 \textrm {kg } \mathrm { ha } ^ { - 1 }}$ \\
\hline \\
organic manure Veget - dosage: $5 \mathrm{tha}^{-1}$ & \\
\hline
\end{tabular}

$\mathrm{N}$ - nitrogen; $\mathrm{P}$ - phosphorus; $\mathrm{K}$ - potassium 
lich II). The climate in the trial area was characterized as continental; the average annual temperature was $9.2^{\circ} \mathrm{C}$, the average temperature of vegetation period was $15.5^{\circ} \mathrm{C}$, the sum of the annual precipitation was $593 \mathrm{~mm}$ (30-year average), the sum of vegetation peri- od precipitation was $358 \mathrm{~mm}$. The weather conditions in the locality Borovce are presented in Table 1. The ground soil preparation was carried out by the conventional method while using share plough in the depth $0.22-0.25 \mathrm{~m}$. The sowing, fertilization and plant treat-

$\mathrm{T}$ a b 1 e 4

The continuous cropping of winter wheat and spring barley

\begin{tabular}{|c|c|c|c|}
\hline $\mathrm{Sq}$ & & & Fertilization \\
\hline \multirow{3}{*}{1} & \multirow{3}{*}{ winter wheat and spring barley are grown in ,net“ monoculture } & $\mathrm{K}$ & mineral fertilizer \\
\hline & & ST & $\begin{array}{l}\text { mineral fertilization } \\
+ \text { straw incorporation }\end{array}$ \\
\hline & & $\mathrm{ST}+\mathrm{VG}$ & $\begin{array}{l}\text { mineral fertilizer } \\
+ \text { straw incorporation }+ \\
+ \text { organic manure Veget }\end{array}$ \\
\hline \multirow{2}{*}{2} & \multirow{2}{*}{ winter wheat and spring barley rotated } & $\mathrm{K}$ & mineral fertilizer \\
\hline & & $\mathrm{ST}+\mathrm{VG}$ & equally in sequence 1 \\
\hline 3 & $\begin{array}{l}\text { winter wheat is interrupted each second year by maize on silage; } \\
\text { spring barley is interrupted each second year by maize on grain }\end{array}$ & $\mathrm{K}$ & mineral fertilizer \\
\hline 4 & winter wheat and spring barley are interrupted each second year by oats & $\mathrm{K}$ & mineral fertilizer \\
\hline
\end{tabular}

$\mathrm{Sq}-$ sequence

$\mathrm{T}$ a b 1 e 5

Analysis of variance of grain yield and thousand kernel weight in crop rotations

\begin{tabular}{|c|c|c|c|c|c|c|c|}
\hline \multirow{2}{*}{ Factor } & \multirow{2}{*}{$\mathrm{df}$} & \multicolumn{3}{|c|}{ Grain yield $\left[\mathrm{t} \mathrm{ha}^{-1}\right]$} & \multicolumn{3}{|c|}{ Thousand kernel weight [g] } \\
\hline & & MS & $\mathrm{F}$ & $\mathrm{LSD}_{0.05}$ & MS & $\mathrm{F}$ & $\mathrm{LSD}_{0.05}$ \\
\hline Fertilization [A] & 1 & 0.08 & 0.51 & - & 0.44 & 0.18 & - \\
\hline SCCR $[B]$ & 2 & $0.80^{+}$ & 5.17 & 0.24 & $13.31^{+}$ & 5.54 & 0.93 \\
\hline $\mathrm{A} \times \mathrm{B}$ & 2 & 0.06 & 0.38 & - & 0.39 & 0.16 & - \\
\hline Year $[\mathrm{C}]$ & 3 & $12.90^{+}$ & 83.35 & 0.30 & $198.12^{+}$ & 82.44 & 1.18 \\
\hline $\mathrm{A} \times \mathrm{C}$ & 3 & $0.58^{+}$ & 3.77 & 0.50 & 1.88 & 0.78 & - \\
\hline $\mathrm{B} \times \mathrm{C}$ & 6 & $0.61^{+}$ & 3.94 & 0.67 & 4.65 & 1.93 & - \\
\hline Error & 69 & 0.16 & & & 2.40 & & \\
\hline Total & 95 & 0.62 & & & 8.91 & & \\
\hline
\end{tabular}

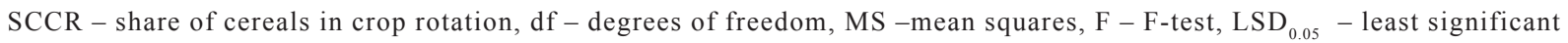
difference at the level $\alpha=0.05$ 
ment were performed in the respectable terms for given area. The pesticide treatments for individual crops were realized according to the current occurrence of diseases, pests and weeds. The long-term field trial consists of two parts. In the first part, the crop rotations were used with 40,60 and $80 \%$ share of the cereals. Table 2 indicates the crops in these rotations. Two levels of fertilization were applied (Table 3). The dosages of $\mathrm{P}$ and $\mathrm{K}$ were calculated according to the balance methodology (Bizík et al. 1998). The determination of nitrogen dosage was calculated by the methodology published by Ložek (1998). In the first part of the trial, winter wheat cultivar Petrana was grown. In the second part of the trial, winter wheat (cv. Petrana and Karolinum) and spring barley were grown in monoculture. To decrease the negative impacts of monoculture growing, various measures were taken, e.g. incorporation of organic matter into the soil and the introduc-

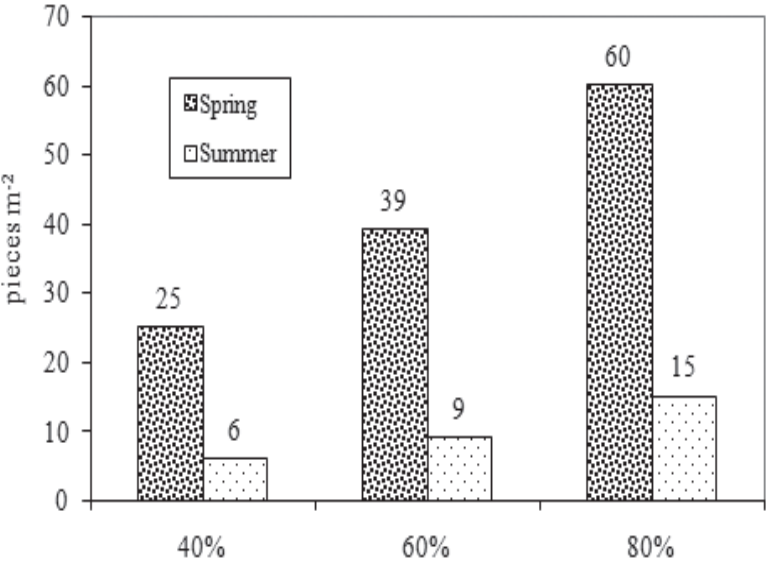

Fig. 1. The weed infestation rate of winter wheat in crop rotations

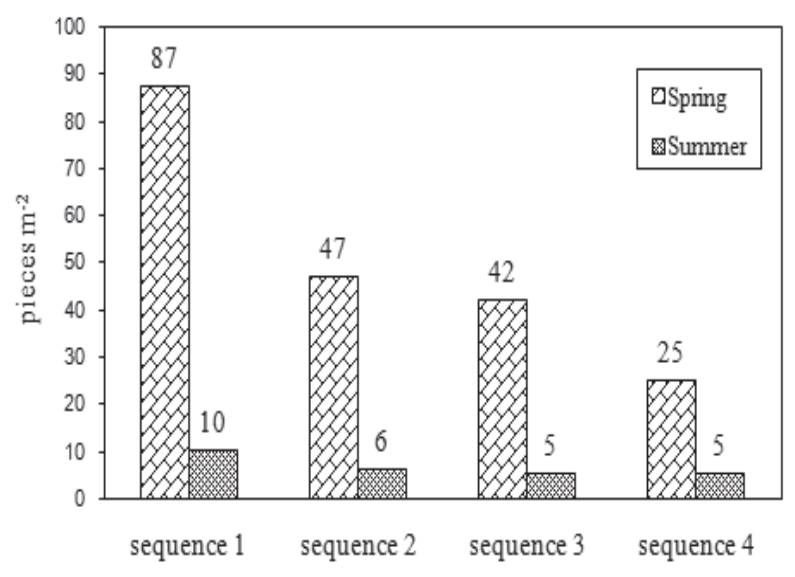

Fig. 2. The weed infestation rate of winter wheat by the continuous cropping

$\mathrm{T}$ a b 1 e 6

The grain yield $\left[\mathrm{t} \mathrm{ha}^{-1}\right]$ of winter wheat in crop rotations

\begin{tabular}{|c|c|c|c|c|c|c|}
\hline SCCR $[\%]$ & Fertilization & 2006 & 2007 & 2008 & 2009 & $\overline{\mathrm{x}}$ \\
\hline \multirow{2}{*}{40} & $\mathrm{H}_{1}$ & 7.58 & 6.12 & 6.32 & 5.68 & 6.43 \\
\hline & $\mathrm{H}_{2}$ & 7.55 & 5.79 & 7.02 & 5.96 & 6.58 \\
\hline \multicolumn{2}{|c|}{$\overline{\mathrm{x}}$} & 7.56 & 5.95 & 6.67 & 5.82 & 6.50 \\
\hline \multirow{2}{*}{60} & $\mathrm{H}_{1}$ & 7.30 & 5.77 & 6.00 & 5.85 & 6.23 \\
\hline & $\mathrm{H}_{2}$ & 7.38 & 5.47 & 6.26 & 5.79 & 6.23 \\
\hline \multicolumn{2}{|c|}{$\overline{\mathrm{x}}$} & 7.34 & 5.62 & 6.13 & 5.82 & 6.23 \\
\hline \multirow{2}{*}{80} & $\mathrm{H}_{1}$ & 6.85 & 5.62 & 6.65 & 5.75 & 6.22 \\
\hline & $\mathrm{H}_{2}$ & 6.88 & 5.33 & 7.04 & 5.71 & 6.24 \\
\hline \multicolumn{2}{|c|}{$\overline{\mathrm{x}}$} & 6.87 & 5.48 & 6.85 & 5.73 & 6.23 \\
\hline \multicolumn{2}{|c|}{$\overline{\mathrm{x}}$} & 7.26 & 5.68 & 6.56 & 5.79 & 6.32 \\
\hline
\end{tabular}

Symbols are identical than the Table 5 
tion of interrupting crops (Table 4). The weed infestation rate was evaluated by ,numerous method' (finding out the number of individual plants of present weed species). The herbicide treatment was applied in the growth stage BBCH 21 after the evaluation of weed infestation rate. The substances active in herbicides were used: in 2006 MCPA, amidosulfuron; in 2007 clopyralid, 2.4-D EHE + florasulam; in 2008 cinidon-ethyl; and in 2009 clopyralid, 2.4-D EHE + florasulam. Grain yield and thousand kernel weight were evaluated by statistical method - analysis of variance. The statistical significance of the data was computed by multipleway analysis of variance (ANOVA). In addition, the LSD multiple range test was used to determine which means differed significantly from the others, using a significance level of $0.05 \%$. These analyses were performed using STATISTICA 6. 1 (StatSoft Inc., Tulsa, USA).

$\mathrm{T}$ a b 1 e 7

The thousand kernel weight $[\mathrm{g}]$ of winter wheat in crop rotations

\begin{tabular}{|c|c|c|c|c|c|c|}
\hline SCCR [\%] & Fertilization & 2006 & 2007 & 2008 & 2009 & $\overline{\mathrm{x}}$ \\
\hline \multirow{2}{*}{40} & $\mathrm{H}_{1}$ & 41.6 & 34.8 & 37.0 & 37.3 & 37.7 \\
& $\mathrm{H}_{2}$ & 40.9 & 35.8 & 37.3 & 38.2 & 38.1 \\
\hline$\overline{\mathrm{x}}$ & & 41.2 & 35.3 & 37.1 & 37.8 & 37.9 \\
\hline \multirow{2}{*}{60} & $\mathrm{H}_{1}$ & 41.4 & 33.8 & 35.0 & 36.0 & 36.6 \\
& $\mathrm{H}_{2}$ & 41.9 & 34.4 & 34.9 & 35.3 & 36.6 \\
\hline$\overline{\mathrm{x}}$ & & 41.6 & 34.1 & 34.9 & 35.7 & 36.6 \\
\hline \multirow{2}{*}{80} & $\mathrm{H}_{1}$ & 42.2 & 35.0 & 36.6 & 36.1 & 37.5 \\
& $\mathrm{H}_{2}$ & 40.9 & 35.7 & 37.4 & 35.6 & 37.4 \\
\hline$\overline{\mathrm{x}}$ & & 41.5 & 35.3 & 37.0 & 35.8 & 37.4 \\
\hline
\end{tabular}

Symbols are identical than the Table 5

$\mathrm{T}$ a $\mathrm{b} 1$ e 8

Analysis of variance of the grain yield and the thousand kernel weight in continuous cropping (sequence 1)

\begin{tabular}{|c|c|c|c|c|c|c|c|}
\hline \multirow{2}{*}{ Factor } & \multirow{2}{*}{ d.f. } & \multicolumn{3}{|c|}{ Grain yield [t ha-1 } & \multicolumn{3}{c|}{ Thousand kernel weight [g] } \\
\cline { 3 - 8 } & & MS & F & LSD $_{0.05}$ & MS & F & LSD $_{0.05}$ \\
\hline Fertilization [A] & 2 & $0.74^{+}$ & 4.49 & 0.36 & 12.06 & 1.11 & - \\
Cultivar [B] & 1 & $1.19^{+}$ & 7.19 & 0.24 & 45.63 & 4.21 & - \\
$\mathrm{A} \times \mathrm{B}$ & 2 & 0.16 & 0.97 & - & 16.73 & 1.54 & - \\
Year [C] & 3 & $35.38^{+}$ & 214.16 & 0.46 & $98.77^{+}$ & 9.14 & 3.72 \\
$\mathrm{~A} \times \mathrm{C}$ & 6 & 0.09 & 0.55 & - & 27.22 & 2.51 & - \\
$\mathrm{B} \times \mathrm{C}$ & 3 & 0.38 & 2.27 & - & $221.58^{+}$ & 20.44 & 6.32 \\
Error & 23 & 0.17 & - & - & 10.84 & - & - \\
Total & 47 & 2.51 & - & - & 33.02 & - & - \\
\hline
\end{tabular}

Symbols are identical than the Table 5 


\section{RESULTS AND DISCUSSION}

From the economic viewpoint, the evaluation of examined factors affects the grain yield, thus more precise differences in grain yield and the growing economy are the most important aspects during the agronomic experiments.

\section{The crop rotations with different share of cereals}

The grain yield

The grain yield of winter wheat was statistically significantly influenced by the share of cereals in crop rotations, weather conditions in particular years, the interaction between fertilization and particular years, and the interaction between the share of cereals and particular years. By $40 \%$ share of cereals in crop rotations (Table 5,6$)$ the substantially higher grain yield was reached $\left(6.50 \mathrm{t} \mathrm{ha}^{-1}\right)$ than by $60 \%$ and $80 \%(6.23$ $\left.\mathrm{t} \mathrm{ha}^{-1}\right)$. In 2007 was grain yield statistically significantly lower $\left(5.68 \mathrm{tha}^{-1}\right)$ than in $2006\left(7.26 \mathrm{tha}^{-1}\right)$ and 2008 $\left(6.56 \mathrm{tha}^{-1}\right)$. In 2007 the overgrow of winter wheat suffered from rainfall deficiency and expressive higher temperatures during the whole vegetation season. The average daily temperature exceeded the long-term normal by: $3.5^{\circ} \mathrm{C}$ in March, $1.9^{\circ} \mathrm{C}$ in April, $1.9^{\circ} \mathrm{C}, 2.4^{\circ} \mathrm{C}$ in May and $2.4^{\circ} \mathrm{C}$ in June. In April there were not any

$\mathrm{T}$ a $\mathrm{b} 1$ e 9

The grain yield $\left[\mathrm{tha}^{-1}\right]$ of winter wheat in continuous cropping (sequence 1)

\begin{tabular}{|c|c|c|c|c|c|c|c|c|c|c|}
\hline \multirow{3}{*}{ Fertilization } & \multirow{2}{*}{\multicolumn{2}{|c|}{$\frac{2006}{\text { Cultivar }}$}} & \multirow{2}{*}{\multicolumn{2}{|c|}{$\frac{2007}{\text { Cultivar }}$}} & \multirow{2}{*}{\multicolumn{2}{|c|}{$\frac{2008}{\text { Cultivar }}$}} & \multirow{2}{*}{\multicolumn{2}{|c|}{$\frac{2009}{\text { Cultivar }}$}} & \multirow{2}{*}{\multicolumn{2}{|c|}{$\overline{\mathrm{x}}$}} \\
\hline & & & & & & & & & & \\
\hline & $\mathrm{P}$ & $\mathrm{K}$ & $P$ & K & $P$ & K & $P$ & K & $P$ & K \\
\hline MF & 2.95 & 2.50 & 2.49 & 2.53 & 6.33 & 6.09 & 4.48 & 4.77 & 4.06 & 3.97 \\
\hline ST & 3.70 & 2.75 & 2.86 & 2.66 & 6.42 & 6.02 & 5.40 & 5.05 & 4.60 & 4.12 \\
\hline $\mathrm{ST}+\mathrm{VG}$ & 3.80 & 2.70 & 2.67 & 2.70 & 6.57 & 6.55 & 5.39 & 4.95 & 4.61 & 4.23 \\
\hline$\overline{\mathrm{x}}$ & 3.48 & 2.65 & 2.67 & 2.63 & 6.44 & 6.22 & 5.09 & 4.92 & 4.42 & 4.11 \\
\hline$\overline{\mathrm{x}}$ & & & & & & & & & & \\
\hline
\end{tabular}

P - cultivar Petrana, K - cultivar Karolinum, MF - mineral fertilizer, ST - incorporation of cereal straw; $\mathrm{ST}+\mathrm{VG}$ - incorporation of cereal straw and organic fertilizer Veget

Other symbols are than in Table 5

$\mathrm{T}$ a b 1 e 10

The thousand kernel weight $[\mathrm{g}]$ of winter wheat in continuous cropping (sequence 1)

\begin{tabular}{|c|c|c|c|c|c|c|c|c|c|c|}
\hline \multirow{2}{*}{ Fertilization } & \multicolumn{2}{|c|}{2006} & \multicolumn{2}{c|}{2007} & \multicolumn{2}{c|}{2008} & \multicolumn{2}{c|}{2009} & \multicolumn{2}{c|}{$\overline{\mathrm{x}}$} \\
\cline { 2 - 14 } & \multicolumn{2}{|c|}{ Cultivar } & \multicolumn{2}{c|}{ Cultivar } & \multicolumn{2}{c|}{ Cultivar } & \multicolumn{2}{c|}{ Cultivar } & \multicolumn{2}{c|}{ Cultivar } \\
\cline { 2 - 13 } & $\mathrm{P}$ & $\mathrm{K}$ & $\mathrm{P}$ & $\mathrm{K}$ & $\mathrm{P}$ & $\mathrm{K}$ & $\mathrm{P}$ & $\mathrm{K}$ & $\mathrm{P}$ & $\mathrm{K}$ \\
\hline \multirow{2}{*}{ MF } & 38.0 & 38.6 & 36.5 & 36.6 & 37.6 & 49.3 & 45.8 & 34.7 & 39.5 & 39.8 \\
$\mathrm{ST}$ & 28.2 & 40.3 & 33.4 & 36.6 & 38.0 & 49.5 & 44.9 & 35.1 & 36.1 & 40.4 \\
$\mathrm{ST}+\mathrm{VG}$ & 41.0 & 45.5 & 35.8 & 36.0 & 36.9 & 45.1 & 43.1 & 35.2 & 39.2 & 40.5 \\
\hline $\bar{x}$ & 35.7 & 41.5 & 35.2 & 36.4 & 37.5 & 48.0 & 44.6 & 35.0 & 38.3 & 40.2 \\
\hline
\end{tabular}

All symbols are than in Table 9 
rainfalls, in June was precipitation deficit $-24.3 \mathrm{~mm}$ in comparison with long-term normal (Table 1). The importance of relations between weather conditions and winter wheat grain yield growing presented Vidovič (2005). He found out that the grain yield of winter wheat in 2001 was statistically significantly higher than in years 1999 and 2000. The difference was $2.4 \mathrm{t} \mathrm{ha}^{-1}$ (38.3\%). The weather conditions enabled to obtain the high winter wheat grain yield $\left(8.6 \mathrm{t} \mathrm{ha}^{-1}\right)$. At the same time was demonstrated that in years with similar soil and climatic conditions as in year 2001 in Borovce, the additional fertilising of the cultivar Astella will not be necessary if we want to achieve the same winter wheat grain yield. Deike et al. (2008) observed the influence of crop rotation, tillage technique and the treatment against Apera spica venti (L.) BEAUV. The grain yield was influenced by the crop rotation in higher measure than tillage intensity and the pesticide treatment. In accordance with results Kováč et al. (2005) and Jamriška et al. (2006) the statistically significant differences between the variants of fertilization were not observed. In our experiments the average grain yield of winter wheat in variant $\mathrm{H}_{1}$ (a combination of mineral fertilization with the use of organic fertilizer Veget) was 6.29 $\mathrm{t} \mathrm{ha} \mathrm{h}^{-1}$ and in variant $\mathrm{H}_{2}$ (mineral fertilization without addition of organic fertilizer Veget) $6.35 \mathrm{t} \mathrm{ha}^{-1}$ (Table 6).

\section{Thousand kernel weight}

By $40 \%$ share of cereals in crop rotations (Table $5,7)$ the significantly higher $(\mathrm{P} \leq 0.05)$ thousand kernel weight (37.9) was determined than by $60 \%$ share of cereals (36.6 g). Similarly, the grain yield in 2007 thousand kernel weight was considerably lower (34.9 g) than in 2006 (41.4 g), 2008 (36.3 g) and 2009 (36.4 g).

\section{Weed infestation rate}

When the proportion of cereals in crop rotations increased, the studies found out a significant increase of the weed infestation rate in winter wheat stands (Fig. $1)$. The lowest weed infestation rate in spring was observed in crop rotation with $40 \%$ share of cereals $(25$ pieces $\mathrm{m}^{-2}$ ). The weed infestation rate by $80 \%$ share of cereals crop rotation after preceding peas crop was 2.4 times higher than by $40 \%$ share of cereals (Fig. 1). In spring the occurrence of the dominating species was observed: Veronica hederifolia (L.), Viola arvensis (L.) MURR., Stellaria media (L.) VIV. And Cirsium arvense (L.) SCOP. The following species dominated in summer: Fallopia convolvulus (L.) LÖVE, Viola arvensis (L.) MURR., Amaranthus retroflexus (L.) and Cirsium arvense (L.) SCOP. In accordance with results Mačuhová (1990), Mikulka (1995) and Týr and Pospišil (1999) was observed that the optimal share of cereals in crop rotations strengthen the competitive press of cereals against weeds. However the pesticide use is necessary in case of the occurrence of perennial weed species. Ulber et al. (2009) investigated that the intensity of crop rotation influence and make clear the change in weed species composition in the highest measure. The results show that the preservation of weed species richness and the maintenance of species with important ecological function require not only timing diversity of crops on crop rotations but also the modification of weed control strategies.

\section{The continuous cropping}

The grain yield

By the continuous cropping of winter wheat (Table 8,9$)$ the average grain yield in the variant with straw and organic manure Veget incorporation was statistically significantly higher $\left(4.42 \mathrm{t} \mathrm{ha}^{-1}\right)$ than in the control variant (4.02 $\left.\mathrm{t} \mathrm{ha}^{-1}\right)$. Similarly Bakht et al. (2009) observed that the incorporation of the harvested remains increases the winter wheat grain yield in the statistically significant degree. In average the incorporation of the harvested remains increases the winter wheat grain yield 1.31 times. Rodrigues-Lizana et al. (2010) proved that $6.7 \mathrm{~kg} \mathrm{ha}^{-1}$ nitrogen and $22.5 \mathrm{~kg} \mathrm{ha}^{-1}$ potassium can be released from the harvested remains of winter wheat. The influence of nitrogen from the different sources, of soil tillage, depth and crop rotation on the winter wheat grain yield, the quality and use of nitrogen were investigated by Montemurro (2009). In accordance with our results it was detected that by mixing organic and mineral fertilization, the highest winter wheat grain yield was reached $\left(5.29 \mathrm{t} \mathrm{ha}^{-1}\right)$. In our experiment the cultivar influenced the grain yield of winter wheat statistically significantly (Table 8). Cultivar Petrana achieved statistically significantly higher grain yield (4.42 $\left.\mathrm{t} \mathrm{ha}^{-1}\right)$ than the cultivar Karolinum (4.11 $\left.\mathrm{t} \mathrm{ha}^{-1}\right)$. The weather conditions in particular years statistically significantly influenced the winter wheat grain yield. In 2008 considerable higher grain yield (6.33 $\left.\mathrm{t} \mathrm{ha}^{-1}\right)$ was determined than in 2006 (3.07 $\left.\mathrm{t} \mathrm{ha}^{-1}\right), 2007$ $\left(2.65 \mathrm{t} \mathrm{ha}^{-1}\right)$ and in $2009\left(5.01 \mathrm{t} \mathrm{ha}^{-1}\right)$. Alvaro-Fuentas et al. (2009) evaluated the influence of continuous crop- 
ping of winter wheat and spring barley on the biomass production, the grain yield and water-use efficiency. All the parameters depended on the rainfall variability found between particular growing seasons. The difference between the highest grain yield of winter wheat in crop rotation with $40 \%$ share of cereals and the average grain yield in continuous cropping of winter wheat represents $34.46 \%\left(2.24 \mathrm{tha}^{-1}\right)$. The value of preceding crop for winter wheat was established by Anderson (2008). Soya, oats - field pea and spring wheat were used as the preceding crops of winter wheat. The winter wheat grain yield was higher by $28 \%$ after mixture: oats - field pea than after spring wheat.

\section{The thousand kernel weight}

The thousand kernel weight was statistically significantly influenced by weather conditions in particular years and by the interaction of cultivar and particular years (Table 8). In 2007 thousand kernel weight (Table $10)$ was significantly lower $(35.8 \mathrm{~g})$ than in 2008 (42.8 g), and 2009 (39.8 g).

\section{Weed infestation rate}

In sequence 1 the average weed infestation rate in spring was 87 pieces $\mathrm{m}^{-2}$ (Fig. 2). The lowest weed infestation rate was in sequence with interrupting crop oats $\left(25\right.$ pieces $\left.\mathrm{m}^{-2}\right)$. The occurrence of dominant species: Veronica hederifolia (L.), Stellaria media (L.) VIV., Viola arvensis (L.) MURR., and Lamiopsis (Lamium) aplexicaule (L.) HOLUB were observed in spring. In summer the highest weed infestation rate of winter wheat was in sequence $1\left(10\right.$ pieces $\left.\mathrm{m}^{-2}\right)$. The lowest weed infestation rate was in sequences with interrupting crops oats and silage maize ( 5 pieces $\mathrm{m}^{-2}$ ). In summer dominated species: Cirsium arvense (L.) SCOP., Fallopia convolvulus (L.) LÖVE and Galium aparine (L.). In accordance with results Koocheki et al. (2009), 11 weed species were observed by continuous cropping of winter wheat. The weed infestation rate of winter wheat was 66 pieces $\mathrm{m}^{-2}$. The change of growing technologies and crop rotation caused the change of weed seeds storage in the soil and weed species composition. For example, by the continuous cropping of winter wheat there was greater occurrence of annual graminaceos weed but higher representation of forbs was in the rotation winter wheat - sugar beet. The weed population in continuous cropping of winter wheat population included $90 \%$ graminaceous weeds and pendulous sedge (Carex), whereas in crop rota- tion sugar beet - winter wheat it was $43 \%$ from whole weed number. The forbs represented $55.2 \%$ in crop rotation sugar beet - winter wheat, but in continuous cropping of winter wheat they represented 9.4\% from whole weed number. The diverse crop rotations which include the crops with different life-cycle e.g. wheat - maize and wheat - sugar beet, can contribute to the decreasing of weed seeds in the soil.

\section{CONCLUSION}

In crop rotation with $40 \%$ share of cereals the grain yield and thousand kernel weight were statistically significantly higher than in crop rotation with $60 \%$ and $80 \%$ share of cereals. The cultivar and fertilization had statistically significant effect on the grain yield by the continuous cropping of winter wheat. By the continuous cropping the thousand kernel weight was statistically significantly influenced weather conditions in particular years and the interaction cultivar and particular years. The winter wheat grain yield in crop rotation with $40 \%$ share of cereals was higher than by continuous cropping (difference $2.24 \mathrm{t} \mathrm{ha}^{-1}$ ).

In spring the weed infestation rate by $80 \%$ share of cereals crop rotation was 2.4 times higher and in summer 2.5 times higher than by $40 \%$ share of cereals. The interrupting of winter wheat continuous cropping with interrupting crops: maize on silage and oats caused the strong decreasing of weed infestation rate.

Acknowledgements. The study was supported by the Ministry of Agriculture of the Slovak Republic, Project No 2006 UO 27/091 05 01/091 0510 "The solution of plant production competitiveness and ecological stability in the regions of Slovak Republic by the farming systems on agricultural land and by the innovation of growing technologies components" and by the Agency for Knowledge and Research: APVV - 0645-06. The title of the project: "The Influence of Share of Cereals on the Soil Physical Properties, Disease Occurrence and Weed Infestation Rate".

\section{REFERENCES}

ALVARO-FUENTAS, J. - LAMPORLANES, J. - CANTEROMARTINEZ, C. 2009. Alternative crop rotations under mediterranean no-tillage conditions: Biomass, grain yield, 
and water-use efficiency. In Agronomy Journal, vol. 101, 2009, no. 5, pp. 1227-1233.

ANDERSON, R.L. 2008. Growth and yield of winter wheat as affected by preceding crop and crop management. In Agronomy Journal, vol. 100, 2008, no. 4, pp. 977-980.

BAKHT, J. - SHAFI, M. - JAN, M.T. - SHAH, Z. 2009. Influence of crop residue management, cropping system and $\mathrm{N}$ fertilizer on soil $\mathrm{N}$ and $\mathrm{C}$ dynamics and sustainable wheat (Triticum aestivum L.) production. In Soil and Tillage Research, vol. 104, 2009, no. 2, pp. 233-240.

BIZÍK, J. - FECENKO, J. - KOTVAS, F. - LOŽEK, O. 1998. Metodika výživy rastlín [Methodics of plant fertilization and nutrition]. Nitra : Slovak Agricultural University. 1998. 112 pp. ISBN 80-967812-1-9

DEIKE, S. - PALLUTT, B. - MELANDER, B. - STRASSEMEYER, J. 2008. Long-term productivity and environmental effects of arable farming as affected by crop rotation, soil tillage intensity and strategy of pesticide use: A case-study of two long-term field experiments in Germany and Denmark. In European Journal Agronomy, vol. 29, 2008, no. 4, pp. 191-199.

ELLMER, F. - BAUMECKER, M. 2005. Soil organic matter of a sandy soil influenced by agronomy and climate. In The role of long-term field experiments in agricultural and ecological sciences \& practical solutions for managing optimum $C$ and $N$ content in agricultural soils III. Praha : Research Institute of Plant Production, 2005. pp. 58-63. ISBN 80-213-1454-0

HOFFMAN, S. - CSITÁRI, G. - BALÁZS, J. - BANKO, L. 2005. Impact of straw manuring on soil organic matter dynamics and fertility. In Book of Abstract International Conference on the Role of Long-term Field Experiments in agricultural and Ecological Sciences. Praha : Výzkumný ústav rostlinné výroby, 2005, pp. 36. ISBN 80-86555-67-4

JAMRIŠKA, P. - MIKLE, F. - FENCÍK, R. 2006. Effect of variety and some agrotechnical treatments on yield and quality of winter wheat (Triticum aestivum L.). In Agriculture (Pol'nohospodárstvo), vol. 52, 2006, no. 1, pp. 14-23.

KOOCHEKI, A. - NASSIRI, M. - ALIMORADI, L. GHORBANI, R. 2009. Effect of cropping systems and crop rotations on weeds. In Agronomy for Sustainable Development, vol. 29, 2009, no. 2, pp. 401-408.

KOVÁC̆, K. - ŽÁK, K. - LEHOCKÁ, Z. 2005. Production and qualitative parameters of winter wheat (Triticum aestivum L.) in integrated and low-input system. In Agriculture (Polnohospodárstvo), vol. 51, 2005, no. 3, pp. 113-121.
LOŽEK, O. 1998. Optimalizácia výživy pšenice ozimnej [The optimalization of winter wheat nutrition]. Nitra : Slovak agriculture university, 1998, 58 pp. ISBN 80-7137-555-1

MAČUHOVÁ, K. et al. 1990. The growing of cereals. Bratislava : Príroda, 1990. 276 pp.

MIKULKA, J. 1995. Effect of herbicides Safari-50DF on weeds in sugar beet. In Proceeding from $13^{\text {th }}$ Czech and Slovak conference about plant control. Praha : VŠZ, 1995. pp. 319-320.

MONTEMURRO, F. 2009. Different nitrogen fertilization sources, soil tillage, and crop rotations in winter wheat: effect on yield, quality, and nitrogen utilization. In Journal of Plant Nutrition, vol. 32, 2009, no. 1, pp. 1-18.

REMEŠOVÁ, I. - HARTMAN, I. - PROCHÁDZKOVÁ, B. 2002. Impact of different soil tillage and straw management on weed species spectrum. In Current trends in the research of soil environment. Troubsko : ISTRO, 2002, pp. $153-158$.

RODRIGUEZ-LIZANA, A. - CARBONELL, R. - GONZÁLEZ, P. - ORDÓNEZ, R. 2010. N, P and K released by the field decomposition of residues of a pea-wheat-sunflower rotation. In Nutrient Cycling in Agroecosystems, vol. 87, 2010, no. 2, pp. 199-208.

RYCHLIK, B - ADAMIAK, J. - WOJCIAK, H. 2005. Dynamics of the soil organic matter in crop rotation and long-term monoculture. In Book of Abstract International Conference on the Role of Long-term Field Experiments in agricultural and Ecological Sciences. Praha : Výzkumný ústav rostlinné výroby, 2005, p. 95, ISBN 80-86555-67-4

StatSoft, Inc. (2003). STATISTICA Cz [Softwarový systém na analýzu dát], verze 6.

TÝR, Š. - POSPIŠIL, R. (1999). The growing of dense-sowing cereals without application of herbicides. In Agriculture (Pol'nohospodárstvo), vol. 45, 1999, no. 2, pp. 108-119.

ULBER, L. - STEINMANN, H.H. - KLIMEK, S. - ISSELSTEIN, J. 2009. An on-farm approach to investigate the impact of diversified crop rotations on weed species richness and composition in winter wheat. In Weed Research, vol. 49, 2009, no. 5, 2009, pp 534-543.

VIDOVIČ, J. 2005. Effect of graded and split nitrogen dressing and forecrop on winter wheat (Triticum aestivum L.) grain yield and its quality. In Agriculture (Pol'nohospodárstvo), vol. 51,2005 , no. 12 , pp. 640-655.

Received: July, $30^{\text {th }}, 2010$ 